\title{
First Amendment Limitations on Public Disclosure Actions
}

In most states truthful public disclosure of private facts ${ }^{1}$ concerning an individual constitutes a tort if the disclosure would be highly offensive to a reasonable person and if the disclosed subject matter is "not of legitimate concern to the public."' If the disclosed subject matter is of legitimate public concern, however, the newsworthiness privilege immunizes the disclosure. ${ }^{3}$

The newsworthiness defense has been established in the case law for over thirty-five years, ${ }^{4}$ and a decade ago the Supreme Court decided Time, Inc. v. Hill ${ }^{5}$ with an opinion that has been widely interpreted as ruling that newsworthiness as a limitation on privacy suits is mandated by the first amendment's guarantee of freedom

' Private facts are those known, at most, to just a few people. See W. Prosser, HANDBooK OF THE LAW OF TorTs $\$ 117$, at 809-11 (4th ed. 1971).

2 Restatement (Second) of Torts $\S 652 \mathrm{D}$ (b) (Tent. Draft No. 21, 1975); Restatement (SECOND) of ToRTs \$ 652D, comments b-d at 113-16 (Tent. Draft No. 13, 1967). The public disclosure tort was spawned by a seminal law review article, Warren \& Brandeis, The Right To Privacy, 4 Harv. L. REv. 193 (1890). For a detailed chronicle of the growth of the privacy tort, see D. Pember, Privacy and the Press (1972).

This comment is concerned with constitutional limitations on actions for public disclosure of private facts. Accordingly, in speaking of "privacy," reference is made only to the interest protected by the public disclosure tort. However, three other torts are conventionally classified with the public disclosure tort under the rubric of privacy actions. See W. Prosser, supra note $1, \S 117$, at 804 . These torts are: (1) "appropriation, for the defendant's benefit or advantages, of the plaintiff's name or likeness," id.; (2) "intrusion upon the plaintiff"s physical solitude or seclusion," id. at 807; and (3) "publicity which places the plaintiff in a false light in the public eye," id. at 812 . This comment is also not concerned with the constitutional right of privacy, which is designed to preserve certain fundamental, personal rights free from governmental interference. See Roe v. Wade, 410 U.S. 113 (1973); Eisenstadt v. Baird, 405 U.S. 438 (1972); Comment, The Constitutional Right of Privacy: An Examination, $69 \mathrm{Nw}$. U.L. REv. 263 (1974). The courts have declined to treat public disclosure suits as actions to vindicate the federal constitutional right to privacy. See, e.g., Morris v. Danna, 411 F. Supp. 1300 (D. Minn. 1976), aff'd per curiam, 547 F.2d 436 (8th Cir. 1977). But cf. Comment, Privacy in the First Amendment, 82 YALE L.J. 1462 (1973) (arguing that the first amendment affirmatively supports a right to privacy).

3 The newsworthiness defense was established as an integral part of the privacy tort by Warren and Brandeis. Drawing an analogy to the qualified privilege of "fair comment" under the common law rules of defamation, they argued that "the right to privacy does not prohibit any publication of matter which is of public or general interest." Warren \& Brandeis, supra note 2 , at 214 .

' Sidis v. F-R Publishing Corp., 113 F.2d 806, 809 (2d Cir.), cert. denied, 311 U.S. 711 (1940). See Comment, The Right Of Privacy: Normative-Descriptive Confusion in the Defense of Newsworthiness, $30 \mathrm{U}$. CHr. L. REv. 722 (1963), an interesting discussion of the newsworthiness privilege at common law.

s 385 U.S. 374 (1967). 
of the press. ${ }^{6}$ Despite this august history, the definition, application, and effect of the newsworthiness privilege remain unsettled. This unresolved conflict between the important and profound interest protected by the public disclosure tort, preservation of a reasonable sense of individual dignity, ${ }^{7}$ and freedom of the press, a basic freedom as well as the guardian of other liberties, has understandably attracted enormous scholarly attention. Constitutional scrutiny of the privacy tort in both the legal literature and the courts has concentrated almost exclusively on the newsworthiness privilege. ${ }^{8}$ The inquiry has focused on the exceedingly difficult problem of formulating a standard of newsworthiness that permits the states to protect legitimate privacy interests in a manner consistent with first amendment freedoms.

The thesis of this comment is that the defense of newsworthiness does not exhaust the constitutional limitations on the public

- Professor Kalven's seminal piece, The Reasonable Man and the First Amendment: Hill, Butts, and Walker, 1967 Sup. CT. Rev. 267, interpreted Justice Brennan's opinion in Hill as establishing that "[n] ewsworthiness defines the ambit of constitutional concern." Id. at 282.

7 The interests protected by the public disclosure tort have been defined and redefined many times. Warren and Brandeis wrote that the principle underlying the right to privacy was "that of an inviolate personality." Warren \& Brandeis, supra note 2, at 205. Another commentator has asserted that the wrong redressed by the public disclosure tort "is to be found in the fact that a private life has been transformed into a public spectacle." Bloustein, Privacy, Tort Law, and the Constitution: Is Warren and Brandeis' Tort Petty and Unconstitutional as Well? 46 TEx. L. REv. 611, 619 (1968). A recent student comment has suggested that three specific privacy interests are affected by public disclosures: "( 1 ) an interest in retaining actual control over the release of information about oneself, for the sake of one's dignity and individuality; (2) an interest in preserving intact (or not, as one sees fit) one's relationships with others; and (3) an interest in how the public perceives one, or reputation." Comment, An Accommodation of Privacy Interests and First Amendment Rights in Public Disclosure Cases, 124 U. Pa. L. Rev. 1385, 1394 (1976). See also A. Westin, Privacy and Freedom (1967); Lusky, Invasion of Privacy: A Clarification of Concepts, 72 Colum. L. Rev. 693 (1972).

This comment defines the interest protected by the public disclosure tort as "a reasonable sense of individual dignity." This formulation is a heuristic device designed to collectively capture the important interests which are at times safeguarded by the public disclosure tort.

* See, e.g., Beytagh, Privacy and a Free Press: A Contemporary Conflict in Values, 20 N.Y.L.F. 453 (1975); Bloustein, supra note 7; Bloustein, The First Amendment and Privacy: The Supreme Court Justice and the Philosopher, 28 Rutgers L. REv. 41 (1974); Kalven, Privacy In Tort Law-Were Warren and Brandeis Wrong? 31 Law \& ConTEMP. ProB. 326 (1966); Kalven, supra note 6; Nimmer, The Right To Speak From Times to Time: First Amendment Theory Applied to Libel and Misapplied to Privacy, 56 CALIF. L. REv. 935 (1968); Phillips, Defamation, Invasion of Privacy, and the Constitutional Standard of Care, 16 SANTA Clara L. Rev. 77 (1975); Comment, The First Amendment Privilege and Public Disclosure of Private Facts, 25 Cath. U.L. Rev. 271 (1976); 5 CAP. U.L. Rev. 267 (1976); 14 DuQ. L. Rev. 507 (1976); 29 VAND. L. REv. 870 (1976). But see Taylor v. K.T.V.B., Inc., 96 Idaho 202, 525 P.2d 984 (1974); Comment, An Accommodation of Privacy Interests and First Amendment Rights in Public Disclosure Cases, 124 U. PA. L. Rev. 1385 (1976). 
disclosure tort. The comment first discusses the relevant Supreme Court and lower court cases and then directly examines the constitutional constraints on the privacy tort. Finally, a model is proposed for accommodating the tort with the first amendment.

\section{Supreme Court Decisions}

No Supreme Court decision squarely addresses the question of the standard of protection afforded by the first amendment for truthful public disclosure of private facts. Indeed, the Court has expressly declined to decide whether the public disclosure tort is in principle compatible with the first amendment. ${ }^{9} \mathrm{~A}$ few cases, however, do provide clues to the Court's thinking on the manner in which freedom of the press circumscribes the public disclosure action.

\section{A. Hill and the Public Interest Test}

In Time, Inc. v. Hill ${ }^{10}$ the Supreme Court reviewed the judgment Hill" had obtained under the New York privacy statute, ${ }^{12}$ which provided an action only if the privacy-invading story was "fictitous." 13 The Court ruled that "the constitutional protections for speech and press preclude the application of the New York statute to redress false reports on matters of public interest in the absence of proof that the defendant published the report with knowledge of its falsity or in reckless disregard of its truth."14 Because the

- Cox Broadcasting Corp. v. Cohn, 420 U.S. 469, 491 (1975).

10 385 U.S. 374 (1967).

"In 1952, James Hill and his family were held hostages in their own home by escaped convicts for nineteen hours, then released unharmed. The Hills' captors were peaceable and courteous. The incident was widely reported at the time but subsequently the Hills moved far away, and Mr. Hill discouraged further publicity of the affair. In 1955, Life magazine ran a story concerning a play based on a novel about a hostage incident involving considerable violence. The story indicated that the play accurately portrayed the Hill incident. The Life story did not damage the Hills' reputation; they were portrayed as courageous in the face of peril. 385 U.S. at 377-78.

12 N.Y. Civ. Rights LaW $\S \S 50-51$ (McKinney 1948).

13385 U.S. at 384 n.9.

is Id. at 387-88. Although this scienter requirement was enunciated in the majority opinion authored by Mr. Justice Brennan, only Justices Stewart and White joined the opinion without qualification. Justices Black and Douglas joined in the opinion only in order to settle the case on the basis of New York Times Co. v. Sullivan, 376 U.S. 254 (1964). This acquiescence was coupled with the stated belief that the New York Times doctrine was "bound to pass away as its applications to new cases proves its inadequacy to protect freedom of the press from destruction in libel cases and other cases like this one." 385 U.S. at 398 (Black \& Douglas, JJ., concurring). Mr. Justice Harlan concurred in the reversal because the New York statute as interpreted by the state courts would permit imposition of liability upon a showing of substantial falsity. Had the New York courts construed the statute to require negligent 
jury had not been instructed that knowledge or reckless disregard of falsity was requisite to a finding of liability, Hill's judgment was reversed and the case remanded..$^{15}$

The Court's argument in support of its decision was brief:

The guarantees for speech and press are not the preserve of political expression or comment upon public affairs, essential as those are to healthy government. One need only pick up any newspaper or magazine to comprehend the vast range of published matter which exposes persons to public view, both private citizens and public officials. Exposure of the self to others in varying degrees is a concomitant of life in a civilized community. The risk of this exposure is an essential incident of life in a society which places a primary value on freedom of speech and of press .... We have no doubt that the subject of the Life article, the opening of a new play linked to an actual incident, is a matter of public interest. ${ }^{16}$

The Court in Hill was careful to distinguish the case before it from both public disclosure ${ }^{17}$ and defamation actions. ${ }^{18}$ But the Court's cautious refusal to say anything about public disclosure actions has not dissuaded commentators from reading Hill as establishing newsworthiness as a complete, constitutionally mandated defense to a public disclosure suit. ${ }^{19}$ Since Hill, lower courts have similarly accorded the newsworthiness defense constitutional stature. ${ }^{20}$

falsification, Harlan would have found that the constitutional requirements were met. 385 U.S. at 402-03 (Harlan, J., concurring).

15 The knowing or reckless falsehood standard, also known as the actual malice standard, was first announced by the Court in New York Times Co. v. Sullivan, 376 U.S. 254 (1964). That landmark case held that a public official could not maintain a libel action for a defamatory falsehood related to his official conduct absent proof that the defamatory statement was made with knowledge that it was false or with reckless disregard of its falsity. See Kalven, The New York Times Case: A Note on "The Central Meaning of the First Amendment," 1964 Sup. CT. Rev. 191. The recklessness disjunct of the actual malice standard has been interpreted to require subjective awareness of probable falsity. St. Amant v. Thompson, 390 U.S. 727, 731 (1968).

is 385 U.S. at 388.

17 Id. at 383 n.7. The Court quoted Sidis v. F-R Publishing Corp., where it was stated: "Revelation may be so intimate and so unwarranted as to outrage the community's notion of decency." 113 F.2d 806, 809 (2d Cir.), cert. denied, 311 U.S. 711 (1940). The court noted that Hill "presents no question whether truthful publication of such matter could be constitutionally proscribed." 385 U.S. at 383 n.7.

ix 385 U.S. at 389-90.

1 See, e.g., G. Gunther, Cases and Materials on Constitutional Law 1279 (9th ed. 1975); Kalven, supra note 6, at 280-81.

20 See, e.g., Virgil v. Time, Inc., 527 F.2d 1122 (9th Cir. 1975), cert. denied, 425 U.S. 998 (1976); Taylor v. K.T.V.B., Inc., 96 Idaho 202, 525 P.2d 984 (1974); McNutt v. New Mexico 
Much of the opinion in Hill supports the inference that the Court implicitly accepted the principle that truthful disclosure of "matters of public interest" cannot constitutionally give rise to liability for invasion of privacy. In one key passage the Court declared that the risk of some public revelations of private facts must be run "in a society which places a primary value on freedom of speech and press," specified way the permissible range of the public disclosure tort. Furthermore, the ground of the Court's ruling that tort liability may not be predicated upon an inaccurate story absent proof of actual malice was not that false speech has any independent first amendment value but rather that tolerance of any less restrictive state-ofmind requirement would discourage true speech about matters of public concern. ${ }^{22}$

Although there is certainly unqualified language in Hill which supports the view that the newsworthiness defense to the public disclosure tort has been constitutionalized, the unusual situation presented by the case counsels caution before acquiescing in that conclusion. The New York court had interpreted the statute that Hill brought suit under as providing a cause of action upon a showing that a report concerning the plaintiff was substantially false, ${ }^{23}$ and Hill had not been required to show that the falsified disclosures seriously infringed his privacy interests. ${ }^{24}$ The combination of that circumstance with the Court's refusal to intimate any views about the public disclosure tort suggests that lower courts and commentators have found more guidance in Hill than is warranted.

State Tribune Co., 88 N.M. 162, 538 P.2d 804 (1975). But see Briscoe v. Reader's Digest Ass'n, 4 Cal. 3d 529, 541, 483 P.2d 34, 42, 93 Cal. Rptr. 866, 874 (1971) (adopting a limited reading of Hill); cf. Commonwealth v. Wiseman, 356 Mass. 251, 261, 249 N.E.2d 610, 617 (1969), cert. denied, 398 U.S. 960 (1970) (distinguishing Hill as a case where the public interest in the dissemination of news was more significant than the privacy interests at stake).

21385 U.S. at 388.

${ }^{22}$ Id. at $388-89$.

${ }^{23}$ See Spahn v. Julian Messner, Inc., 18 N.Y.2d 324, 328-29, 221 N.E.2d 543, 545, 274 N.Y.S.2d 877, 880 (1966).

Although the sole requirement for liability under the New York statute was that the report be substantially false, most commentators refer to Hill as a "false light" action. See, e.g., Nimmer, supra note 8 , at 958 . False light actions are predicated upon the defendant's placing the plaintiff in a false light before the public eye in a manner highly offensive to a reasonable person in the plaintiff's position. See REstatemENT (SECOND) OF TORTS $\S 652 \mathrm{E}$ (Tent. Draft No. 21, 1975). The unorthodox nature of the suit in Hill helps explain the Court's statement in Cantrell v. Forest City Publishing Co., 419 U.S. 245, 250-51 (1974), that it had no occasion to inquire whether the Hill standard applied to all false light cases.

2s Professor Kalven noted that, in their preoccupation "with the role of 'falsity' in erasing the newsworthiness privilege, [the New York courts] have not looked to see if there was a prima facie invasion of privacy in the first place that required the protection of a privilege to avoid liability." Kalven, supra note 6, at 281 n.36. 


\section{B. The Gertz Retrenchment}

Recent developments in the area of libel law might further undercut the view that, when faced with the question, the Court will hold that publication of newsworthy stories-stories that deal with matters of public interest-may never serve as the basis for privacy liability. In Gertz $v$. Robert Welch, Inc. ${ }^{25}$ the Court disapproved the position a plurality of the Court had taken in Rosenbloom v. Metromedia, Inc. ${ }^{26}$ that "all discussion and communication involving matters of public or general concern" warrant the protection from liability afforded by the knowing or reckless falsehood standard. ${ }^{27}$ In part, the position of the Rosenbloom plurality was disapproved because the Court did not wish to require "state and federal judges to decide on an ad hoc basis which publications address issues of 'general or public interest' and which do not-to determine, in the words of Mr. Justice Marshall, 'what information is relevant to selfgovernment." "'28 Instead of adopting a public interest test to trigger the actual malice requirement, the Court held that "so long as they do not impose liability without fault, the States may define for themselves the appropriate standard of liability for a publisher or broadcaster of defamatory falsehood injurious to a private individual."'29 The knowing or reckless falsehood standard, the Court stated, is required only where the defamed individual is a public figure. ${ }^{30}$

The Court did not spell out why judges are unfit to apply the "matter of public interest" test. It may be that the justices felt that the determination of whether a story addresses matters of public concern is such an intractable inquiry that adoption of the test would result in uncertainty in libel law, an uncertainty that would intolerably inhibit freedom of the press. Alternatively, judicial ad. ministration of the public interest test may have been thought to

25418 U.S. 323 (1974).

${ }^{26} 403$ U.S. 29 (1971). Chief Justice Burger and Justice Blackmun joined Justice Brennan's opinion which announced the decision of the Court. Id. at 30 . Justices Black and White concurred only in the judgment. Id. at 57.

${ }^{27} \mathrm{Id}$. at 44.

2* 418 U.S. at 346 . On its face, this criticism is directed only at a newsworthiness defense defined in terms of the relevance of the disclosed subject matter to self-government. See Bloustein, supra note 7, at 61, 90; see generally A. MEIKLEJohn, Poltical Freedom (1960). Justice Marshall's objection would apply, however, to any formulation of the newsworthiness defense which requires judges or juries to assess the utility and public importance of the particular privacy-invading speech.

29 U.S. at 343.

${ }^{30} \mathrm{Id}$. 
violate the principle that restrictions on speech be content-neutral. ${ }^{31}$ One commentator has even suggested that the Court's reluctance to require judges to evaluate the public interest in speech was partly founded upon a realization of the undemocratic nature of judicial review..$^{32}$ Whatever the rationale, the rejection of the public interest test as not meet for judicial judgment was not linked to any particular feature of defamation.

The implications for the public disclosure tort of the Gertz Court's rejection of the public interest test in defamation cases are somewhat difficult to discern. The consequences of declining to adopt a public interest test in the two contexts differ greatly. The function of the public interest test in Rosenbloom was to define the circumstances in which the knowing or reckless falsehood standard must be applied. Since Gertz, the public figure test has been used instead of the "matter of public interest" test to determine whether knowing or reckless falsehood, rather than some lesser degree of fault, must be shown. In a defamation case, deciding whether the plaintiff is or is not a public figure, and thereby deciding whether the actual malice or fault test applies, does not conclude the case in either party's favor. ${ }^{33}$

In contrast, the function of the public interest test in privacy cases is to determine whether the speech at issue is of high first amendment value. The speech involved in defamation cases, since false, has no constitutional value ${ }^{34}$ True speech that is of legitimate concern to the public, on the other hand, is important to the citizens qua governors, helps preserve the balance between stability and change, and often serves as a means of self-fulfillment. ${ }^{35}$ If speech is of high first amendment value, it is generally immune from regu-

"See text and notes at notes 117-119 infra.

32 Note, 9 GA. L. REv. 963,970 n.24 (1975).

${ }^{33}$ The applicability of the Gertz public figure/private figure distinction in the privacy context is uncertain. Gertz offered two reasons for distinguishing among defamation plaintiffs. First, public officials and public figures are less vulnerable to lasting reputational injury because they have greater access to "the channels of effective communication and hence have a more realistic opportunity to counteract false statements than private individuals normally enjoy." 418 U.S. at 344 . Second, the news media are "entitled to act on the assumption that public officials and public figures have voluntarily exposed themselves to increased risk of injury from defamatory falsehood concerning them." Id. at 345. Although the second rationale for the distinction can be extended to the privacy context-it is no more of a conclusory fiction to say that public figures have consented to invasions of privacy than to say they have consented to reputational injury-the first rationale cannot. More publicity will only exacerbate the invasion of privacy, not correct it. See Nimmer, supra note 8, at 961 .

${ }^{34}$ Gertz v. Robert Welch, Inc., 418 U.S. 323, 340 (1974).

${ }^{35}$ For a discussion of the values promoted by the first amendment, see T. EMErson, ThE SYSTEM OF FrEEDOM OF EXPRESSION (1970). 
lation or prohibition..$^{36}$ Under modern first amendment doctrine it is unlikely that the gravity of the evil caused by a public disclosure, individual dignitary injury, is ever great enough to justify restricting newsworthy speech. Thus, failure to recognize a public interest test in public disclosure actions would render the tort unconstitutional. Faced with such a result, the Court might overcome its uneasiness regarding the public interest test. ${ }^{37}$

\section{Cox Broadcasting Corp. v. Cohn}

The only public disclosure suit to reach the Supreme Court suggests that some form of newsworthiness limitation upon public disclosure actions is constitutionally required. In Cox Broadcasting Corp. v. Cohn $n^{38}$ the Court ruled that the Supreme Court of Georgia erred in holding that Cohn, the father of a deceased rape victim, could constitutionally maintain a privacy action against defendants who had identified the victim by name during television coverage of the trial of the alleged rapists. ${ }^{39}$ The Court held that the first amendment proscribes the imposition of sanctions for the accurate publication of a rape victim's name obtained from judicial records open to public inspection.

Identifying the rule of law established in Cohn proves somewhat difficult. On the one hand, the Court reasoned that there could, under the circumstances, be no actionable invasion of privacy because "the commission of crime, prosecutions resulting from it, and judicial proceedings arising from the prosecutions, are without question events of legitimate concern to the public and consequently fall within the responsibility of the press to report the operations of government." ${ }^{40}$ At this juncture, the Court seemed to be

36 See, e.g., Erznoznick v. City of Jacksonville, 422 U.S. 205 (1975); Brandenburg v. Ohio, 345 U.S. 444 (1969). The least protective test applied to high-value speech in recent years was the discounted clear and present danger standard employed in Nebraska Press Ass'n v. Stuart, 427 U.S. 539, 562 (1976). See generally Symposium: Nebraska Press Association v. Stuart, 29 STAN. L. REv. 383-626 (1977). In that case the Court apparently applied the test only because there was no need to determine if the restraint would be invalid under a more protective test. It is unlikely that a discounted clear and present danger test will be given general applicability.

${ }^{37}$ In Time, Inc. v. Firestone, 424 U.S. 448, 455 (1976), the Court, faced with the argument that the matter of legitimate concern to the public language in Cox Broadcasting Corp. $v$. Cohn, 420 U.S. 469 (1975), signaled a return to Hill and Rosenbloom, declared that the Cohn test should be restricted to suits involving truthful reports and should not be invoked in the libel area because defamation involves false and inaccurate statements.

2* 420 U.S. 469 (1975), noted in 5 CAP. U.I. REv. 267 (1976); 14 DuQ. L. Rev. 507 (1976);

24 EMORY L.J. 1205 (1975); 9 GA. L. REv. 963 (1975).

31 Cox Broadcasting Corp. v. Cohn, 231 Ga. 60, 200 S.E.2d 127 (1973), rev'd, 420 U.S. 469 (1975).

so 420 U.S. at 492 (emphasis added). 
operating within the conceptual framework of the Hill case, declaring speech protected because it concerns events or matters of public interest. Accordingly, the Court found no need to evaluate the social utility of broadcasting the name of a rape victim. It would be incautious, however, to conclude that the Court has completely overcome the misgivings voiced in Gertz concerning the "matter of legitimate interest" test. The Court did not discuss the Gertz retrenchment at all, and it did set forth two additional rationales for decision which are not dependent upon case-by-case judicial determination of what disclosures address matters of public concern.

First, the Court declared that "[p]ublic records by their very nature are of interest to those concerned with the administration of government, and a public benefit is performed by the reporting of the true contents of the record by the media." 41 Fleshing out this position, the Court noted that public records contain vital information about governmental operations, that the citizenry is entitled to know about the operations of government, and that even the most concerned citizens would lack important information without fearless press coverage of the public record. ${ }^{42}$ Furthermore, Justice White, writing for the Court, suggested that Georgia "[b]y placing the information in the public domain on official court records . . . must be presumed to have concluded that the public interest was thereby being served." 43

At first glance, this ground for decision seems unsupportable. The generalization that information on the public record is of legitimate public concern appears to admit of numerous exceptions, a paradigmatic example being a rape victim's name. The Court did not attempt to demonstrate any connection between publicizing the name of a rape victim and self-government, fair trials, or any other public concern. On the contrary, the public has a positive interest in preventing the publication of the name of a rape victim-to avoid deterring future rape victims from reporting rapes to the police. ${ }^{44}$ Likewise, the Court's reliance on Georgia's assessment of the public interest in speech is hard to understand because the Court is certainly not prepared to defer questions concerning the scope of first amendment freedoms to state legislatures for resolution.

The Court, however, was undoubtedly aware that the profferred

"Id. at 495.

12 Id. at $491-92$.

${ }^{43}$ Id. at 495.

"Policy arguments for and against affording constitutional protection to the publication of a rape victim's name are collected in D. Pember, Privacy and the Press 202 (1972). 
generalization was flawed. The key to understanding this ground of the decision is contained in the following passage:

We are reluctant to embark on a course that would make public records generally available to the media but forbid their publication if offensive to the sensibility of the supposed reasonable man. Such a rule would make it very difficult for the press to inform their readers about the public business and yet stay within the law. The rule would invite timidity and selfcensorship and very likely lead to the suppression of many items that would otherwise be put into print and that should be made available to the public. ${ }^{45}$

Due to its reservations, expressed in Gertz, about the ability of judges to evaluate the public utility of speech, yet unwilling to unnecessarily admit that the public disclosure tort cannot coexist with the first amendment, the Court seized on the generalization that public records are often the repository of information possessing high first amendment value and ruled that the generalization should not brook exception. Moreover, the Court declared, "We are reluctant to embark on a course that would make public records generally available to the media but forbid their publication if offensive to the sensibilities of the supposed reasonable man. . . . The rule would invite timidity and self-censorship." 46 The Court in Cohn remained committed to "a strategy that requires that speech be overprotected in order to assure that it is not underprotected";47 it was not persuaded that there exist sufficiently certain and administrable standards for permitting some public disclosure actions to succeed without inhibiting the press from publishing admittedly important material.

Buttressing the result dictated by its first two grounds of decision, the Court argued that, as recognized by the common law public records defense to a privacy action, there is no substantial privacy interest in information already on the public record. ${ }^{48}$ Although the Court was less than explicit, the argument seems to be that because no legitimate privacy interests are infringed by giving publicity to public information, it is unconstitutional to impose sanctions on the press for printing such information, regardless of its importance. ${ }^{49}$

15420 U.S. at 496 .

"Id.

17 Kalven, supra note 15, at 213.

4 420 U.S. at 493-96.

1" The Court relied on the following passage from the commentary to the Restatement 
This argument rests on a false premise. Although it is true that a public disclosure action lies only if the facts disclosed are not widely known, it is disingenuous to suggest that all facts on the public record are public facts, in the sense that they are known to a substantial number of people. Giving publicity to little-known facts in the public record may appreciably affect individual privacy. ${ }^{.0}$

The Cohn case has been discussed as if the Court treated the three grounds of decision as independently sufficient. However, it should be emphasized that the Court took care to restrict its holding to cases involving official records of judicial proceedings. ${ }^{51}$ It is impossible to predict whether Cohn will be extended to protect all disclosures of matters of legitimate public concern or even to protect all disclosures of information contained in the public record.

To summarize the imbroglio of Supreme Court decisions that provide any indication as to the manner in which the first amendment restricts the scope of the public disclosure tort, the Court has committed itself only to the narrow holding of Cohn and has left most of the area uncharted. In particular, the Court has criticized yet at times invoked the "matter of legitimate concern to the public" test, adopted a bifurcated test turning on the nature of the plaintiff in the related area of libel, and assessed the injury to privacy interests where the information disclosed was obtained from judicial records open to the public. It has declined either to embrace any principles for general resolution of the first amendment issues involved in public disclosure actions or to rule the tort unconstitutional.

\section{Lower Court Cases}

Lacking specific guidance from the Supreme Court, the lower courts have treated the constitutional limitations on public disclosure actions disparately. ${ }^{52}$ Five strikingly different approaches are

of Torts: "[T]here is no liability for giving publicity to information about the plaintiff which is already public. Thus there is no liability for giving publicity to facts about the plaintiff's life which are matters of public record." RESTATEMENT (SECOND) of TORTS § 652D, comment c at 114 (Tent. Draft No. 13, 1967), quoted in 420 U.S. at 494.

so Few citizens bother to investigate the general public record, and empirical studies have found that public access to information in the public record is often severely restricted by bureaucratic inertia. See, e.g., Research Study-Public Access to Information, 68 Nw. U.L. REv. 177 (1973).

31420 U.S. at $491,496$.

52 As long as the reach of the public disclosure tort was viewed solely as a matter of common law, the administration of public disclosure actions properly varied from jurisdiction to jurisdiction. The newsworthiness privilege turned on the demonstrable public interest, Meetze v. Associated Press, 230 S.C. 330, 95 S.E.2d 606 (1956), the plaintiff's status as a public figure vel non, Harms v. Miami Daily News, 127 So. $2 \mathrm{~d} 715$ (Fla. Ct. App. 1961), the 
discernible in the recent case law. ${ }^{53}$ The cases generally accord constitutional status to the newsworthiness defense, and struggle to define its contours. These lower court efforts will be explained, categorized according to their most unusual feature, and evaluated in terms of their capacity to meet the challenge implicitly put by the Supreme Court in Cohn: the development of administrable standards for the trial of public disclosure suits that permit some deserving plaintiffs to recover and at the same time afford solid, certain protection to first amendment liberties.

\section{A. Demonstrable Public Interest}

Due perhaps to understandable trepidation at defining the legitimate public interest, some courts have defined newsworthiness by reference to the popular interest in the particular private facts disclosed..$^{54}$ The difficulties with this approach are illustrated by the

nature and purpose of the publication, Sellers v. Henry, 329 S.W.2d 214 (Ky. 1959), and the offensiveness of the publication, Gill v. Hearst Pub. Co., 40 Cal. 2d 224, 239 P.2d 630 (1952). Moreover, there was no agreement on the division of function between judge and jury in determining whether a publication was privileged. Compare Barber v. Time, Inc., 348 Mo. 1199, 159 S.W.2d 291 (1942), and Sellers v. Henry, 329 S.W.2d 214 (Ky. 1959), with Wheeler v. P. Sorensen Mfg. Co., 415 S.W.2d 582 (Ky. 1967), and Meetze v. Associated Press, 230 S.C. 333, 95 S.E.2d 606 (1956).

The propriety of variety disappears with the recognition that the first amendment delimits the permissible scope of the tort. See Pennekamp v. Florida, 328 U.S. 331, 335 (1945). This proposition may be thought refuted by the Court's decision in Miller v. California, 413 U.S. 15 (1973). In Miller the Court held that the factual determination of obscenity is to be made by application of contemporary community standards, not national standards. This conclusion did not, for the Court in Miller, entail rejection, only qualification, of the principle that first amendment guarantees are constant nationwide.

Under a National Constitution, fundamental First Amendment limitations on the powers of the States do not vary from community to community, but this does not mean that there are, or should or can be, fixed, uniform national standards of precisely what appeals to the "prurient interest" or is "patently offensive." These are essentially questions of fact, and our Nation is simply too big and too diverse for this Court to reasonably expect that such standards could be articulated for all 50 States in a single formulation, even assuming the prerequisite consensus exists.

Id. at 30. See also Jenkins v. Georgia, 418 U.S. 153 (1974).

${ }^{33}$ What may be termed the enigmatic approach to the constitutional defense of newsworthiness has found favor with some courts. That is to say, judges often declare that a particular article, photograph, or broadcast is or is not newsworthy without offering any supporting analysis or explanation. See, e.g., Afro-American Publishing Co. v. Jaffe, 366 F.2d 649, 654 (D.C. Cir. 1966); Deaton v. Delta Democrat Publishing Co., 326 So. 2d 471, 474 (Miss. 1976); Williams v. KCMO Broadcasting Div., Meredith Corp., 472 S.W.2d 1, 5 (Kan. Ct. App. 1971). See also Commonwealth v. Wiseman, 356 Mass. 251, 249 N.E.2d 610 (1969), cert. denied, 398 U.S. 960 (1970), criticized in Comment, The "Titticut Follies" Case: Limiting the Public Interest Privilege, 70 COLUM. L. REv. 359 (1970).

st See, e.g., Jenkins v. Dell Publishing Co., 251 F.2d 447 (3d Cir. 1958); Sidis v. F-R Publishing Corp., 113 F.2d 806 (2d Cir.), cert. denied, 311 U.S. 711 (1940); Hazlitt v. Fawcett Publications, 116 F. Supp. 538 (D. Conn. 1953); McNutt v. New Mexico State Tribune Co., 
case of McNutt v. New Mexico State Tribune Co. ${ }^{55}$ Five police officers and their wives brought a privacy action when their names and addresses were published in a newspaper report of a gun battle between the officers and two members of a group known as the "Black Berets," both of whom were killed. Prior to publication of the story, the city editor ${ }^{56}$ of the defendant newspaper had called the plaintiff policemen seeking information about the shoot-out. Following instructions from their superiors, the policemen declined to discuss the incident; the editor threatened to print the plaintiffs' names and addresses because of their refusal to cooperate. The names were published and after publication the officers received anonymous phone calls threatening violence.

The trial court granted the defendants' motion for summary judgment. The Court of Appeals of New Mexico affirmed, ruling that the names and addresses of the plaintiffs were newsworthy as a matter of law. After recognizing that newsworthiness is a constitutionally required defense to a public disclosure action, ${ }^{57}$ the court in McNutt defined newsworthy private facts as those "relatively current events such as in common experience are likely to be of public interest." 58 In applying this test, however, the New Mexico court did not draw on its experience to speculate on the range of popular interest in the plaintiffs' names and addresses. ${ }^{59}$ Instead, the names and addresses were newsworthy because "[i]t is the usual practice in newspaper accounts to identify persons by giving their names and addresses ....."

$M c N u t t$ illustrates that when newsworthiness is defined in terms of the demonstrable public interest in the particular facts disclosed, courts will not ordinarily review a publisher's decision that a particular story is newsworthy ${ }^{61}$ Publishers generally print only what they believe to be of interest to their readers, and judges

88 N.M. 162, 538 P.2d 804 (1975). Except for McNutt, decisions employing a popular interest standard were decided before the newsworthiness defense was constitutionalized. See text and notes at notes 21-24 supra. The popular interest standard has been expressly rejected by some courts. See, e.g., Rawlins v. Hutchinson Publishing Co., 218 Kan. 295, 304-05, 543 P.2d 988, 996 (1975).

5588 N.M. 162, 538 P.2d 804 (1975).

58 The city editor was named as an individual defendant.

5788 N.M. at $166-67,538$ P.2d at 808-09.

ss Id. at 167, 538 P.2d at 809 (quoting Jenkins v. Dell Publishing Co., 251 F.2d 447, 451 (3d Cir. 1958)).

5) The plaintiffs conceded that the gun battle was newsworthy. 88 N.M. at 167,538 P.2d at 809 .

so Id. at 167,538 P.2d at 809.

- See Comment, The Right of Privacy: Normative-Descriptive Confusion in the Defense of Newsworthiness, 30 U. CHI. L. REv. 722, 725-26 (1963). 
are wisely hesitant to second-guess the publisher's business judgment. Moreover, there are no standards by which judges can quantitatively assess the popular interest in a particular news item. ${ }^{62}$ Even an uninteresting article published in a popular journal may be widely read. The test of newsworthiness advanced in $M c N u t t$ thus protects editorial discretion. ${ }^{63}$ This result, however, is gained at the cost of eviscerating the privacy tort with respect to mass media defendants.

More importantly, the demonstrable public interest test fails to pass constitutional muster when applied to non-media defendants. ${ }^{64}$ An individual who is not professionally engaged in mass-media reporting cannot claim to be an unerring judge of the public interest. Although judges presumably could assess evidence as to the size of a speaker's audience or the readership of a hand-distributed pamphlet, findings on these matters have little, if any, relevance to deciding whether the speech involved is constitutionally important. ${ }^{65}$ Consider, for example, an individual who discloses private facts about a public official that directly bear on the official's fitness for office. This speech is constitutionally protected even if the speaker's audience is so insouciant or disaffected with politics that the speech is paid no attention. In a word, the standard of newsworthiness espoused in McNutt is both over- and under-inclusive.

\section{B. Defendant's Motives}

It might be thought that the constitutional privilege to give publicity to private facts should not extend to individuals who dis-

${ }^{82}$ Cf. Kalven, supra note 8, at 336 ("[S]urely there is force to the simple contention that whatever is in the news media is by definition newsworthy, that the press must in the nature of things be the final arbiter of newsworthiness.").

is The constitutional mandate to preserve editorial discretion was emphasized in Miami Herald Publishing Co. v. Tornillo, 418 U.S. 241 (1974). See also Cantrell v. Forest City Publishing Co., 484 F.2d 150, 156-57 (6th Cir. 1973), rev'd on other grounds, 419 U.S. 245 (1974) ("The judgment of what is newsworthy must remain primarily a function of the publisher . . . . Only in cases of flagrant breach of privacy which has not been waived or obvious exploitation of public curiosity where no legitimate public interest exists should a court substitute its judgment for that of the publisher.").

"This is not to suggest that freedom of press is guaranteed to individuals. See Miami Herald Publishing Co. v. Tornillo, 418 U.S. 241, 254 (1974); Gertz v. Robert Welch, Inc., 418 U.S. 323 (1974); Columbia Broadcasting System, Inc. v. Democratic National Committee, 412 U.S. 94, 113 (1973). Rather, it is submitted that defining the constitutional protection for the public disclosure of private facts in terms of the popular interest in the publicized facts unconstitutionally abridges freedom of speech. See generally Nimmer, Introduction-Is Freedom of the Press a Redundancy: What Does It Add to Freedom of Speech? 26 Hastings L.J. 639 (1975).

is Such evidence would be relevant to determining whether the facts had been publicized, however. See text and note at note 1 supra. 
close private facts out of objectionable motives. ${ }^{66}$ In Taylor $v$. K.T.V.B., Inc. ${ }^{67}$ the Supreme Court of Idaho may have adopted this view. An Idaho television station broadcast a film clip showing Taylor being arrested and taken from his home in the nude. Taylor brought a privacy action against the station and recovered a judgment in the trial court. On appeal, the Supreme Court of Idaho reversed. The court recognized that speech concerning matters on which the public is entitled to be informed, such as the conduct of police officers and those they arrest, ${ }^{68}$ is presumptively protected, but ruled that this protection is forfeited if the "disclosure was made with 'malice,' i.e. for the purpose of embarrassing or humiliating [the subject of the disclosure], or with reckless disregard as to whether that disclosure will result in such embarrassment or humiliation." ${ }^{9}$ Because the jury had not been instructed that a finding of "malice" was a prerequisite to recovery, the court held that the defendant television station was entitled to a new trial. ${ }^{70}$

The Taylor opinion may be read in two ways. On the one hand, the Idaho court quoted a number of authorities for the proposition that reports of arrests, including identifications of arrestees, are newsworthy. ${ }^{71}$ In stating its holding, however, the court declared: "Use of material of a highly offensive nature for the purpose of embarrassment of an arrestee, or with reckless disregard for the embarrassing aspects of it is not necessary to keep the public informed."'72

If the court meant that although the arrest was of legitimate public concern, the film of Taylor's private parts was not, the decision is commendable. Adding to newsworthiness a standard of care requirement sensibly increases the protection given to speech. If,

${ }^{36}$ In 1974 the Supreme Court held that truth was a constitutionally required unconditional defense to a defamation action. Gertz v. Robert Welch, Inc., 418 U.S. 323 (1974). At one time, however, a number of states required that the defendant in a defamation suit show good motives or justifiable ends in addition to truth. See Franklin, The Origins and Constitutionality of Limitations on Truth as a Defense in Tort Law, 16 STAN. L. REv. 789, 790 (1964).

6796 Idaho 202, 525 P.2d 984 (1974).

68 Id. at 204-06, 525 P.2d at 986-88.

69 Id. at $205-06,525$ P.2d at $987-88$.

${ }^{70}$ The Idaho court purported to follow Gertz v. Robert Welch, Inc., 418 U.S. 323 (1974), and New York Times Co. v. Sullivan, 376 U.S. 254 (1964), in establishing the malice requirement. 96 Idaho at 206,525 P.2d at 988 . This reliance is inappropriate because the actual malice standard in defamation cases protects negligent and innocent falsehoods only because a contrary rule would inhibit truthful speech concerning matters of public importance. See Gertz, 418 U.S. at 340; New York Times Co., 376 U.S. at 278-80. The court in Taylor stood the malice requirement on its head, employing it to withdraw constitutional protection from truthful speech.

796 Idaho at 204-05, 525 P.2d at 986-87.

72 Id. at 206,525 P.2d at 988 . 
however, the court meant to rule that disclosures made with "malice" are never worthy of constitutional protection, then the doctrine of the Taylor case is disturbing indeed.

Under the latter interpretation of Taylor, whether a disclosure is constitutionally protected turns solely on the speaker's state of mind. First, if the defendant is shown to have been subjectively aware that the publication or broadcast in question would embarrass or humiliate the plaintiff, the defendant's newsworthiness defense is defeated. The constitutional defects of such a rule are obvious. For example, the disclosure of official corruption might well embarrass the politicans involved, yet such a disclosure is of undeniable constitutional significance. ${ }^{73}$ The standard of care requirement does not render the test constitutionally permissible; unless the disclosure is deceptively inoffensive, freedom of the press is guaranteed only to insentient publishers.

Second; the disclosure is unprotected if the defendant's purpose was to embarrass or humiliate the plaintiff. This branch of the Taylor malice test is superficially more attractive; it may appear that a constitutionally important distinction can be drawn between stories designed to inform and stories designed to embarrass an individual. The first amendment has not been thought a bar to recovery for the intentional infliction of emotional distress. ${ }^{74}$ Moreover, the standard is administrable-triers of fact often determine an individual's motives. ${ }^{75}$ Upon examination, however, the rule is inconsistent with the first amendment. The first amendment preserves the public's right to be informed on matters of public importance. ${ }^{76}$ The Taylor test, in contrast, focuses on the blameworthiness of the speaker. As a consequence, people will refrain from giving publicity to private facts of legitimate public interest. Those who

${ }^{73}$ See, e.g., Garrison v. Louisiana, 379 U.S. 64, 67 (1964); New York Times Co. v. Sullivan, 376 U.S. 254, 273 (1964).

"See generally W. ProssER, supra note $1, \S 12$. The criticism of Taylor advanced herein, however, implies that if the act complained of in a suit for the intentional infliction of emotional distress consists of the accurate publicizing of newsworthy private facts, the first amendment precludes the action. See text and notes at 76-77 infra.

${ }^{75}$ For example, in an action for malicious prosecution, the jury determines whether the defendant instituted the proceeding maliciously. W. ProssER, supra note $1, \S 119$.

${ }^{76}$ See, e.g., Time, Inc. v. Hill, 385 U.S. 374, 387-88 (1967); A. MeikLejohn, Political Freedom (1960); Brennan, The Supreme Court and the Meiklejohn Interpretation of the First Amendment, 79 HaRv. L. Rev. 1 (1965). This is not to suggest that the only purpose of the first amendment is to guarantee the people's right to be informed on matters of public concern. Self-expression is an end in itself, a part of self-fulfillment. Moreover, free speech may be cathartic for those who might otherwise express themselves violently. The first amendment serves these purposes. See Whitney v. California, 274 U.S. 357, 375 (1927) (Brandeis, J., concurring). 
would speak out of malice will be silenced by the threat of tort liability. Because it cannot be assumed that a disinterested individual will always have the access to private facts of public importance enjoyed by an interested adversary, silencing the malicious speaker may deny the public newsworthy information. Moreover, a personally disinterested individual with access to private facts of legitimate public interest will be inhibited from making them public by the possibility that it will be proved in court that he spoke out of hatred. ${ }^{77}$ In its concern to do justice between the parties to a privacy suit, the Taylor rule thwarts the public rights guaranteed by the first amendment.

\section{Consent}

It is an established principle of tort law that consent of the victim may immunize acts that would otherwise amount to actionable torts. ${ }^{78}$ Accordingly, consent has long been a recognized defense to a mass disclosure suit. ${ }^{79}$ However, some recent privacy decisions ${ }^{80}$ have confounded the common law defense of consent with the constitutional defense of newsworthiness and have employed a notion of consent to determine whether a publication was constitutionally protected in cases where the express or implied consent necessary to waive a tort action was lacking.

These decisions are of two types, those openly admitting the element of consent and those speaking of "public figures," and are exemplified by Neff $v$. Time, Inc. ${ }^{81}$ and Rawlins $v$. Hutchison Publishing Co., ${ }^{82}$ respectively. In Neff a federal district court held that the publication of a photograph of a football fan with the zipper of his trousers open was constitutionally privileged because the fan was one of a group that had encouraged and posed for the photographer. ${ }^{83}$ In Rawlins the Kansas Supreme Court ruled that a former

7 The Supreme Court emphasized similar factors in striking down a criminal defamation statute that punished false statements if made with ill-will. Garrison v. Louisiana, 379 U.S. 64, 73 (1964).

${ }^{73}$ See W. Prosser, supra note $1, \S 18$, at 101-08.

79 Id. $\S 117$, at 817 .

ko See, e.g., Neff v. Time, Inc., 406 F. Supp. 858 (W.D. Pa. 1976); Briscoe v. Reader's Digest Ass'n, 4 Cal. 3d 529, 483 P.2d 34, 93 Cal. Rptr. 866 (1971) (consent treated as one factor to be considered in deciding if a privacy-invading publication was constitutionally protected); Rawlins v. Hutchison Publishing Co., 218 Kan. 295, 543 P.2d 988, 993 (1975). But see Williams v. KCMO Broadcasting Division, Meredith Corp., 472 S.W.2d 1, 4 (Kan. App. 1971) (first amendment privilege applied even though the individual publicized was involved in a newsworthy event against his will).

st 406 F. Supp. 858 (W.D. Pa. 1976).

*2 218 Kan. 295, 543 P.2d 988 (1975).

\&3 406 F. Supp. at 859-62. 
police officer could not, consistently with the first amendment, maintain a public disclosure suit based on a newspaper account of his official misconduct because he, as a public figure, had "waived" his right to privacy with respect to facts bearing on his fitness for office. ${ }^{84}$

The danger fostered by the idioms of consent and public figure is that courts will rely on slogans and catchwords instead of analyzing the privacy and first amendment interests at stake in a particular case. Neff and Rawlins illustrate this problem. Although it is difficult to quarrel with the result in either case-no private facts were disclosed in Neff ${ }^{85}$ and the story objected to in Rawlins disclosed facts of legitimate public concern-both opinions avoid precise identification of the reasons a public disclosure action is or is not constitutionally permissible under the circumstances. As generalizations such statements as "public figures enjoy only a very limited right of privacy" may be true, but their invocation impedes rather than promotes the proper resolution of individual cases. Attention must be paid to the considerations underlying the generalizations in order to determine whether a particular plaintiff may maintain a public disclosure action.

There are at least two reasons why a public figure is generally less likely to successfully prosecute a privacy suit than is a private individual. Knowledge of why the generalization obtains leads to appreciation of the need to dispense with it. First, the actions of public figures are likely to be of legitimate interest. For example, a report disclosing that the United States ambassador to the United Nations used foul language in a private meeting with the Ugandan ambassador should not give the United States ambassador a right of action for invasion of privacy because the fact disclosed is of legitimate public concern. Moreover, disclosure of even the most private facts about a public official, such as a serious drinking problem, may promote informed exercise of the franchise. Second, public figures may find it difficult to establish that their privacy has been invaded. To recover in a privacy action, the plaintiff must prove that the disclosure of private facts about which he complains would be highly offensive to a reasonable person in his position. Movie stars often expect, indeed trade on, public interest in their personal lives. Whether a particular plaintiff's privacy has been unreasonably violated turns upon a determination of the plaintiff's

8t 218 Kan. at 300-01, 543 P.2d at 993-96.

is The court in Neff recognized that the fact disclosed in the photograph had been made public already by the plaintiff. $406 \mathrm{~F}$. Supp. at 861 (alternative holding). 
position and the degree of privacy one in that position could reasonably expect to preserve.

It should be evident that the reasons a public figure can be said to "enjoy only a limited right to privacy" do not obtain across the board. The task of developing administrable standards to accommodate privacy interests with first amendment rights cannot be accomplished simply by inquiring whether the plaintiff is a public figure. The first amendment does not command that those who advertently enter into public life surrender their rights to any degree of privacy. Conversely, important and newsworthy private facts may concern an otherwise obscure individual. Defining "public figure" so as to single out those persons about whom particular private facts become, by choice or accident, of legitimate public concern merely rephrases the problem of determining what private facts are newsworthy. ${ }^{86}$ There is no substitute for the identification and evaluation of the privacy and first amendment interests at issue in each public disclosure case.

\section{The California Approach}

The California courts have developed a unique approach to resolving the first amendment issues in public disclosure actions. In Melvin v. Reid ${ }^{87}$ a California appellate court declared that even though the biography of a rehabilitated prostitute once accused of murder was newsworthy, the prostitute's name was not. The California Supreme Court subsequently adopted this distinction between events, which are almost always of public interest, and identification of individuals, which may not be. In Kapellas $v$. Kofman ${ }^{88}$ the court ruled that an editorial describing a political candidate's family problems was protected, while in Briscoe $v$. Reader's Digest Association ${ }^{89}$ the court held that the public interest in identification of a rehabilitated truck hijacker may be outweighed by the state's and the individual's interest in rehabilitation and privacy. ${ }^{90}$

${ }^{8 s}$ In Time, Inc. v. Firestone, 424 U.S. 448,455 (1976), the Court indicated that the determination of who is a public figure for the purpose of invoking the actual malice standard is not divorced from an ascertainment of the legitimate interests of the public. See also Comment, An Accommodation of Privacy Interests and First Amendment Rights in Public Disclosure Cases, 124 U. PA. L. REv. 1385, 1415 (1976) (suggesting that adoption of the public figure/private figure distinction in the privacy context in lieu of the public interest test would have no practical significance). But see Phillips, supra note 11, at 80-85.

87112 Cal. App. 285, 297 P. 91 (1931).

xx 1 Cal. 3d 20, 459 P.2d 912, 81 Cal. Rptr. 360 (1969).

x9 4 Cal. 3d 529, 483 P.2d 34, 93 Cal. Rptr. 866 (1971), noted in 60 Calif. L. Rev. 1042 (1972); 5 Loy. L.A. L. REv. 544 (1972).

${ }^{90} 4$ Cal. 3 d at 537, 483 P.2d at 40,93 Cal. Rptr. at 872 . Surprisingly, the district court 
The California cases have been criticized by some commentators as inviting judicial "censorship." 91 The doctrine does in fact appear to require intrusive judicial scrutiny of a kind likely to cause uncertainty in editorial offices. The formula for decision involves consideration of "[1] the social value of the facts published; [2] the depth of the article's intrusion into ostensibly private affairs; and [3] the extent to which the party voluntarily acceded to a position of public notoriety."92 No threshold of dignitary injury is required; apparently the court must in each case strike a balance unstructured by straightforward and administrable doctrines. The flexibility and comprehensiveness of the social utility test is achieved at the expense of predictability and ease of administration.

The California courts' focus on whether disclosure of the plaintiff's identity is of public interest, however, promotes principled adjudication of public disclosure suits. Assessing the public interest in identifying particular individuals is more tractable than determining what subjects or what private facts are of legitimate public concern. ${ }^{93}$ Individual privacy is not seriously injured by privacyinvading stories which do not identify individuals; by focusing on the very aspect of the publication that triggers the claim of invasion, the California courts have made an important contribution.

\section{E. Offensiveness}

Virgil v. Time, Inc. ${ }^{94}$ arose out of a Sports Illustrated article on body surfing at an especially dangerous California beach known as the "Wedge." 95 The plaintiff, Mike Virgil, was reputed to be the most daredevil body surfer at the Wedge. Virgil granted interviews ${ }^{96}$ to the writer of the magazine story, but objected to the story's publi-

on remand granted summary judgment for the defendant. H. NELSON \& D. TEETER, LAw of Mass Communications 199 (2d ed. 1973).

"Pember \& Teeter, Privacy and the Press since Time, Inc. v. Hill, 50 Wash. L. Rev. 57, 81 (1974).

22 Kapellas v. Kofman, 1 Cal. 3d 20, 36, 459 P.2d 912, 922, 81 Cal. Rptr. 360, 370 (1969).

${ }^{93}$ See text and notes at notes 133-151 infra.

" 527 F.2d 1122 (9th Cir. 1975), cert. denied, 425 U.S. 998 (1976), noted in 29 VAND. L. Rev. 870 (1976).

${ }^{25}$ The article, entitled The Closest Thing to Being Born, appeared in the Feb. 22, 1971 issue of Sports Illustrated.

${ }^{9}$ Because Virgil himself revealed the allegedly private facts to the reporter, the defendant contended that Virgil had made the facts public or, alternatively, that Virgil had consented to the magazine's disclosing the private facts. Id. at 1126-27. The Ninth Circuit rejected the former contention, reasoning that disclosure to a single person, even a reporter, is not a disclosure to the public at large. Id. As to the alternative argument, the court ruled that consent may be revoked prior to publication unless, perhaps, as was not the case in Virgil, "an eleventh-hour change of mind . . . would unfairly burden the publisher." Id. at 1127 n.6. 
cation upon learning that it contained "a series of anecdotes about him which emphasize the psychological characteristics which presumably explain the reckless disregard for his own safety which his surfing demonstrates." When efforts to halt publication of the story failed, Virgil brought suit for invasion of privacy. ${ }^{98}$

On appeal from the district court's denial of Time's motion for summary judgment, ${ }^{99}$ the Ninth Circuit directly examined the nature of the limits imposed by the first amendment on the public disclosure action. The court of appeals began its constitutional analysis of the privacy tort by stating that the purpose of the first amendment is to protect the public's "right to know," and that the public's right to know is defined by the newsworthiness defense. ${ }^{100}$ In delineating the ambit of the defense the court turned to the Restatement (Second) of Torts. According to the Restatement, a publication is newsworthy, and hence constitutionally protected, if it concerns a matter of "legitimate concern to the public."101 The court quoted the following passage from the Restatement commentary, observing that it "expresses the distinction between that which is of legitimate public interest and that which is not"102 as well as the court could:

In determining what is a matter of legitimate public interest, account must be taken of the customs and conventions of the community; and in the last analysis what is proper becomes a matter of community mores. The line is to be drawn when the publicity ceases to be the giving of information to which the public is entitled, and becomes a morbid and sensational prying into private lives for its own sake with which a reasonable member of the public, with decent standards, would say that he had no concern. ${ }^{103}$

In a footnote to this passage the court declared: "We do not intend

${ }^{97}$ Id. at 1124. These anecdotes related, among other things, how Virgil had extinguished a lighted cigarette in his mouth, had eaten insects, and had dived down a flight of stairs for no apparent reason beyond impressing "chicks." Id. at 1124-25 n.1.

${ }^{9 \times}$ The suit was brought in a California state court. It was removed to the United States District Court for the Southern District of California on grounds of diversity by the defendant. Id. at 1123.

${ }^{87}$ It was a certified interlocutory appeal, taken under 28 U.S.C. $\$ 1292($ b) (1970). 527 F.2d at 1123 .

${ }^{100} 527$ F.2d at 1128. See also Bloustein, supra note 8, at 56-59; Meiklejohn, The First Amendment is an Absolute, 1961 Sup. CT. REv. 245, 255.

101 Restatement (SECOND) of ToRTs $\S 652 \mathrm{D}$ (Tent. Draft No. 21, 1975).

${ }^{102} 527$ F.2d at 1129 (footnote omitted).

${ }^{103}$ Id. at 1129 (quoting Restatement (Second) of TorTs $\S 652 \mathrm{~F}$, comment f at 130 (Tent. Draft No. 17, 1967)). 
that 'morbid and sensational' be taken too literally. This is not, in our view, to be regarded as a statement of a prerequisite, but rather as illustrative of the degree of offensiveness which should be present."104

Having adopted this standard for newsworthiness, the court proceeded to determine whether the district court's denial of summary judgment was proper. It ruled that the "privilege" of newsworthiness, because dependent on community mores, was a question for the jury, and that the propriety of summary judgment depended on whether "reasonable minds could differ" on the issue. ${ }^{105}$ Summary judgment for the defendant would therefore be proper only if "the answer on which reasonable minds agree favors invocation of the privilege." 100 The court vacated the district court's order denying summary judgment and remanded for consideration of whether jury questions regarding the "state of community mores" were presented by the facts of the case. ${ }^{107}$

On one plausible reading of its opinion, the Ninth Circuit in Virgil adopted what Professor Hill has called the "unconscionability" standard. ${ }^{108}$ Under this test, the disclosure must be of a "shocking character" before liability attaches. ${ }^{108}$ This rule of liability is itself subject to two variant interpretations, each of which finds some support in different language in the Virgil opinion.

First, the offensiveness or unconscionability standard may be applied so that whenever a disclosure of private facts shocks a decent member of the community, it is constitutionally unprotected. By declaring that the newsworthiness defense is the sole constitutional privilege and defining newsworthiness in terms of offensiveness, ${ }^{110}$ the court may have adopted this variant of the unconscionability test. This rule of law is insufficiently protective of first amendment freedoms. Disclosure of information which shocks reasonable

${ }^{104}$ Id. at 1129 n.11.

105 Id. at 1131.

${ }_{106} I d$.

${ }^{107}$ Id. In particular, the Ninth Circuit stressed that the district court should, in ruling on the defendant's motion, have the benefit of its recent decision in Guam Federation of Teachers Local 1581 v. Ysrael, 492 F.2d 438 (9th Cir.), cert. denied, 419 U.S. 872 (1974). 527 F.2d at 1130-31. See generally Monaghan, First Amendment "Due Process, " 83 Harv. L. Rev. 518 (1970); Comment, Privacy and Summary Judgment: New Tests, New Beneficiaries, 6 Seton Hall L. REv. 454 (1975).

ros Hill, Defamation and Privacy under the First Amendment, 76 Colum. L. Rev. 1205, $1262 \& \mathrm{n} .271$ (1976).

100 Id. at 1258.

110527 F.2d at 1128-29 \& n.11. 
people is at times important speech. The test is unacceptable both because it allows the imposition of sanctions on speech of paramount constitutional importance and because a judge or jury determination of extreme offensiveness is quite unpredictable.

There is, however, a second interpretation of the offensiveness test employed in Virgil which finds support in the Restatement commentary quoted. The commentary states that a disclosure is unprotected only when "it ceases to be the giving of information to which the public is entitled, and becomes a morbid and sensational prying into private lives for its own sake."111 In this passage the court appears to have adopted a test which, contrary to its earlier statement that newsworthiness defines the extent of constitutional protection, requires that a disclosure be both offensive and unnewsworthy in order to lack constitutional protection. On this view the community's sense of decency operates as a criterion of legitimacy in addition to and independently of the criterion of political or social importance. This is a speech-protective test which, properly clarified, administered, and supplemented, can adequately accommodate the right to privacy with the first amendment. ${ }^{112}$ The court in Virgil, however, did not work out in any principled way the constructs of the test. ${ }^{113}$

\section{First Amendment Limitations on the Privacy Tort}

The failure of the privacy cases decided in the ten years since Time, Inc. v. Hill'14 to develop workable standards for reconciling legitimate privacy interests with the first amendment is traceable in part to the assumption that newsworthiness is the exclusive first amendment limitation on the public disclosure tort. ${ }^{115}$ The newsworthiness privilege is indeed one limitation on the permissible scope

111 Id. at 1129.

112 See text and notes at notes 120-151 infra.

113 On remand, the district court somewhat surprisingly granted the defendant's motion for summary judgment. Virgil v. Sports Illustrated, 424 F. Supp. 1286 (S.D. Cal. 1976).

II 385 U.S. 374 (1967).

IIs One virtue of admitting additional constitutional defenses is to relieve the pressure to define the single constitutional limitation on privacy actions presently recognized, newsworthiness, in terms which require a judge or jury to indiscriminately consider the extent to which privacy interests are damaged, see, e.g., Virgil v. Time, Inc., 527 F.2d 1122 (9th Cir. 1975), cert. denied, 425 U.S. 998 (1976); Briscoe v. Reader's Digest Ass'n., 4 Cal. 3d 529, 483 P.2d 34, 93 Cal. Rptr. 866 (1971), and the publisher's need for certainty, see, e.g., Cantrell v. Forest City Publishing Co., 484 F.2d 150 (6th Cir. 1973), rev'd on other grounds, 419 U.S. 245 (1974), as well as the public's legitimate interest in the facts disclosed. As the examination of the lower court case law undertaken above demonstrates, commingling these judgments in a single verbal formula without specifying the circumstances under which each is to be controlling leads to unprincipled and often unconstitutional decisions. 
of the privacy tort. The public disclosure of private facts that are of legitimate public concern can never serve as the basis for tort liability. Speech on matters of public interest is of high first amendment value and absolutely immune from prohibition. ${ }^{116}$

For this reason, public disclosures of private facts of legitimate public concern must be distinguished from disclosures of private facts of no legitimate public concern in order to secure any area for the public disclosure tort to operate. This distinction might be thought to run afoul of the principle that "above all else, the First Amendment means that the government has no power to restrict expression because of its message, its ideas, its subject matter or its content."117 However, the rationale for the rule that restrictions on speech be content-neutral does not fully apply to the distinction between speech that addresses matters of public concern and speech that does not. As Mr. Justice Stevens, writing for a plurality of the Court in Young $v$. American Mini Theatres, ${ }^{118}$ stated:

The essence [of the rule against content distinctions] is the need for absolute neutrality by the Government; its regulation of communication may not be affected by sympathy or hostility for the point of view being expressed by the communicator. Thus, although the content of a story must be examined to decide whether it involves a public figure or a public issue, the Court's application of the relevant rule may not depend on its favorable or unfavorable appraisal of that figure or that issue. ${ }^{119}$

${ }^{116}$ See text and notes at notes 34-37 supra.

17 Police Dep't of Chicago v. Mosley, 408 U.S. 92, 95 (1972) (ordinance held violative of the equal protection clause of the fourteenth amendment because it impermissibly distinguished between labor picketing and other peaceful picketing). See also Erznoznik v. City of Jacksonville, 422 U.S. 205, 208-12 (1975) (ordinance making it a punishable offense for a drive-in movie to exhibit films containing nudity when the screen is visible from a public place held violative of the first amendment because it discriminated among protected speech solely on the basis of content).

IIs 427 U.S. 50 (1976). Five Justices did not assent to the plurality's holding that nonobscene, sexually explicit speech is entitled to less than full first amendment protection. However, the Court has assented to the proposition quoted in the text-that the level of first amendment protection accorded speech turns on content. See, e.g., Bates v. State Bar of Arizona, 97 S. Ct. 2691, 2699 (1977); Virginia State Bd. of Pharmacy v. Virginia Citizens Consumer Council, Inc., 425 U.S. 748, 771 n.24 (1976).

i' 427 U.S. at 67-68 (1976). A second rationale for the ban on content distinctions was once offered by the Court: "Any restriction on expressive activity because of its content would completely undercut the "profound national commitment to the principle that debate on public issues should be uninhibited, robust, and wide-open.' "Police Dep't of Chicago v. Mosley, 408 U.S. 92, 96 (1972) (quoting New York Times Co. v. Sullivan, 376 U.S. 254, 270 (1964)). This rationale is not only consistent with the distinction between speech regarding matters of public importance and speech concerning private matters, it incorporates the distinction. 
Newsworthiness, however, cannot define the entire "ambit of constitutional concern" 120 in privacy cases. Defining the first amendment limitations solely in terms of newsworthiness ignores the constitutional problems inherent in the imposition of sanctions on true speech that neither injures nor threatens to injure any significant interest that the government might seek to protect.

True nonnewsworthy speech is entitled to a measure of first amendment protection. The Supreme Court has declared that the categories of speech that the first amendment in nowise protects include speech that is "no essential part of any expression of ideas"121 and "of slight social value as a step to truth."122 On this test all true statements of fact enjoy first amendment protection. ${ }^{123}$ The Court has long abandoned the view, if it was ever accepted, that the first amendment protects only speech which contributes to the political process. ${ }^{124}$ Permitting innocuous speech that does not address matters of public importance furthers the value of individual selfexpression. ${ }^{125}$ More importantly, as Professor Hill has pointed out, Supreme Court obscenity cases properly suggest that the first amendment is concerned with protecting speakers from government control regardless of the worth of their expression:

[The cases] indicate, in their development, an increasing sense that the value embodied in the freedom of speech clause is not merely the cultivation of uninhibited expression with a view to the potential contribution of such expression to the common good, but more fundamentally the protection of the speaker from governmental restraint-a sense that the speaker has a right to be let alone in the absence of compelling reasons to the contrary. ${ }^{126}$

120 Kalven, supra note 6; at 283.

${ }^{21}$ Chaplinsky v. New Hampshire, 315 U.S. 568, 572 (1942).

122 Id. See also Virginia State Bd. of Pharmacy v. Virginia Citizens Consumer Council, Inc., 425 U.S. 748, 762 (1976) (commercial speech is protected).

${ }^{123}$ Similarly, the court has declared that "there is no constitutional value in false statements of fact," Gertz v. Robert Welch, Inc., 418 U.S. 323, 340 (1974), and perhaps the negative inference that there is some constitutional value in all true statements of fact can properly be drawn.

124 See, e.g., Virginia State Bd. of Pharmacy v. Virginia Citizens Consumer Council, Inc., 425 U.S. 748 (1976) (commercial speech protected); Curtis Publishing Co. v. Butts, 388 U.S. 130 (1967) (actual malice standard in libel suits extended from public officials and candidates to public figures).

${ }^{123}$ It has long been recognized that one of the values served by the first amendment is individual self-expression. E.g., Whitney v. California, 274 U.S. 357, 375 (1927) (Brandeis, J., concurring).

${ }^{128}$ Hill, Defamation and Privacy under the First Amendment, 76 Colum. L. Rev. 1205, 1208 \& n.9 (1976). Professor Hill quotes the following famous passage from Stanley v. Georgia, 
The degree of protection afforded by the first amendment to privacy-invading speech that does not concern matters of legitimate public interest has not been established by the Supreme Court. However, the appropriate standard for determining the circumstances under which the first amendment value of such speech is outweighed by significant, ${ }^{127}$ competing interests is already in operation, although not as a constitutional standard. It is the widely accepted but often misinterpreted requirement for maintenance of a public disclosure action that the disclosure be highly offensive to a reasonable person in the plaintiff's position. ${ }^{128}$ The function of the offensive disclosure requirement, properly understood, is to describe the class of facts which an individual reasonably and understandably could want to keep private. Individual privacy is a widely and deeply held value. The requirement thus operates to pick out those disclosures which the state has a significant interest in sanctioning. In sum, the newsworthiness defense and the offensive disclosure requirement circumscribe the privacy tort, the newsworthiness de-

394 U.S. 557, 565 (1969): "If the First Amendment means anything, it means that a State has no business telling a man, sitting alone in his own house, what books he may read or what films he may watch." As Professor Hill recognizes, later decisions have indicated that the privacy of the home was the touchstone of the Stanley opinion. See, e.g., Paris Adult Theatre I v. Slaton, 413 U.S. 49, 66 (1973); United States v. Twelve 200-Ft. Reels, 413 U.S. 123, 126 (1973). However, the tripartite test of Miller v. Califomia, 413 U.S. 15, 24 (1973), itself indicates that speech which lacks serious social value is protected unless it appeals to the prurient interest and depicts sexual conduct in a patently offensive way. Generalizing, unimportant speech is protected unless seriously harmful.

127 Some decisions regarding restrictions on expression related to issues of public importance provide imperfect analogies to the middle-level protection accorded by the significant interest test. See, e.g., Grayned v. City of Rockford, 408 U.S. 104, 114-21 (1972) (reasonable "time, place and manner" restrictions permissible if necessary to further significant government interests); United States v. O'Brien, 391 U.S. 367, 376 (1968) (when a course of conduct includes speech and nonspeech elements, "a sufficiently important governmental interest in regulating the non-speech elements can justify incidental limitations on First Amendment freedoms."). See also Virginia State Bd. of Pharmacy v. Virginia Citizens Consumer Council, Inc., 425 U.S. 748,771 n.24 (1976) (dictum) (commercial speech protected, yet a different degree of protection is necessary to protect commercial speech than, for example, political commentary); Young v. American Mini Theatres, 427 U.S. 50, 70-71 (plurality of the Court holds that sexually explicit but nonobscene speech may be subjected to more rigorous time, place, and manner restrictions than other speech).

${ }^{12 \pi}$ In the privacy context, "offensiveness" is a chameleonlike word used in at least four different senses: 1) to characterize those private facts disclosure of which constitutes a public disclosure tort, see W. Prosser, supra note $1, \S 117$, at $811 ; 2$ ) to describe the manner or context in which private facts are disclosed, see O'Hilderbrandt v. Columbia Broadcasting System, Inc., 40 Cal. App. 3d 323, 333-34, 114 Cal. Rptr. 828, 833 (1974); Comment, The Right of Privacy: Normative-Descriptive Confusion in the Defense of Newsworthiness, $30 \mathrm{U}$. CHI. L. Rev. 722, 725-26 n.17 (1963); 3) to characterize the reasonable public reaction which must exist before a disclosure is actionable, see Virgil v. Time, Inc., 527 F.2d 1122 (9th Cir. 1975), cert. denied, 425 U.S. 998 (1976); and 4) in this comment, to characterize when the plaintiff's privacy interests are seriously aggrieved. 
fense because it distinguishes speech that cannot be regulated or prohibited at all from that which can, and the offensiveness requirement because it identifies those cases in which privacy interests outweigh first amendment interests. The remaining question is how these constitutional limitations should be spelled out and effectuated. Recognizing that in this area of the law, more so than in most, it is easier to be critical than correct, the remainder of this comment is devoted to working out the full complex of constraints which should be placed on privacy suits.

\section{Accommodating the Public Disclosure Tort with the First Amendment: A Proposed Model}

\section{A. The Offensive Disclosure Requirement}

The requirement for maintenance of a public disclosure action that the disclosure be highly offensive to a reasonable person in the plaintiff's position does not mean, as one influential commentator has written, "that the matter made public must be one which would be offensive and objectionable to a reasonable man of ordinary sensibilities." 129 The function of the offensive disclosure requirement is not to define those facts that the public or the individual whom the facts concern would reasonably find offensive. Such a standard would ill serve the interests protected by the privacy tort and scarcely qualify as a candidate for defining the scope of constitutional protection accorded privacy-invading publications that are not of public interest. Instead, the offensive disclosure requirement describes those facts an individual reasonably wishes to keep private. For example, publication of the intimate details of an individual's marital life should be actionable, not because the facts disclosed are in any way offensive, but rather because the privacy of such facts is essential to preservation of a reasonable sense of individual dignity. The distinction is between offensive facts and facts the disclosure of which is offensive.

A rule that would withdraw constitutional protection from unnewsworthy speech because the facts disclosed turned out to be offensive to the "reasonable plaintiff," however, would transgress the principle that a publisher "cannot be required to guess." 130 Supplementing the offensive disclosure requirement as a prerequisite to liability, the first amendment requires that it be shown that the

129 W. Prosser, supra note $1, \S 117$, at 811.

${ }^{130}$ Winters v. New York, 333 U.S. 507, 515 (1948). See also Time, Inc. v. Hill, 385 U.S. 374,389 (1967). 
defendant knew, or in the exercise of reasonable care should have known, that the disclosure would be highly offensive to a reasonable man in the plaintiff's position.

The duty of reasonable care should be narrowly construed. It should not import a duty to inquire about the plaintiff's circumstances. Absent actual knowledge that the disclosure is offensive, the reasonable care standard should preclude liability if the disclosure complained of is not, on its surface, destructive of reasonable privacy interests. A standard that would require the press to undertake additional inquiries or research would inadequately respect its need for quick decisions. ${ }^{131}$ Requiring a publisher to read what he prints and to make a reasonable judgment whether a story seriously harms privacy interests, however, would not impose an undue burden; under this standard, a publisher need not be correct, merely sensible. Similarly, when a reporter or writer has a story about an individual that he reasonably believes is not destructive of significant privacy interests, he should be able to write it without having to inquire further into the subject's circumstances. To illustrate, suppose a publisher runs a story written by an independent contractor ${ }^{132}$ disclosing private facts concerning an individual, believing on the

131 A standard of care defense is also required by the constitutional principle that an individual must be given notice as to when his speech can serve as a predicate for criminal or civil liability, lest the exercise of free speech rights be inhibited. See Hamling v. United States, 418 U.S. 87, 120-24 (1974) (to sustain a conviction for mailing obscene brochures in violation of 18 U.S.C. $\$ 1461$ (1970), the first amendment requires that the prosecution show that the defendant had knowledge of the character and nature of the material distributed). See also Smith v. California, 361 U.S. 147, 151-55 (1959).

Professor Kalven once wondered whether a standard of care has a role to play in public disclosure cases. Kalven, supra note 8, at 334-35. Bloustein responded that the only conceivable situation in which reasonable care could constitute a defense to a public disclosure action is when "a publisher utters an account of another's personal life intending and attempting not to identify the person involved, but, in fact, the publication is identifiable as concerning him." Bloustein, Privacy, Tort Law, and the Constitution: Is Warren and Brandeis' Tort Petty and Unconstitutional as Well? 46 TEx. L. Rev. 611, 617 (1968). He added, "The settled rule concerning motive in intentional torts and in defamation actions is that, as long as the act constituting the wrong was intended, it is no defense that the consequence of the act was not. Why should anyone suppose the rule would vary in right to privacy cases?" Id. The view espoused in this comment is that Kalven's question is more suggestive than Bloustein supposed: privacy-invading publications can be deceptively innocuous, but the first amendment mandates that notice be given to publishers before restrictions are placed on their right to print accurate stories.

${ }^{132}$ The author's knowledge may be attributed vicariously to his publisher if and only if the author would be classified as an employee under traditional agency principles. See Cantrell v. Forest City Publishing Co., 419 U.S. 245, 253-54 (1974); Gertz v. Robert Welch, Inc., 418 U.S. 323, 331-32 (1974); Hotchner v. Castillo-Puche, 551 F.2d 910 (2d Cir. 1977). For one view on the appropriateness of the respondeat superior doctrine in defamation suits, see Robertson, Defamation and the First Amendment: In Praise of Gertz v. Robert Welch, Inc., 54 TEx. L. REv. 199, 246-47, 266-68 (1976). 
basis of the facts known to him that the story does not identify the individual. Liability should not attach in this situation even if readers more familiar with the plaintiff's circumstances make the connection, provided that the story does not, on its face, identify the plaintiff.

\section{B. Newsworthiness}

Determining whether speech concerns a matter of legitimate public interest is extraordinarily difficult. The architect of the public speech/private speech distinction, Professor Meiklejohn, argued that the absolute guarantee of the first amendment is "assured only to speech which bears, directly or indirectly, upon issues with which voters have to deal." ${ }^{133}$ Dr. Meiklejohn's standard of relevance is quite expansive, however, for in his view speech concerning education', philosophy, literature, science, and the arts is of "governing importance" because a sensitive and aware electorate requires knowledge of these subjects. ${ }^{134}$

The influence of Professor Meiklejohn's views on the Supreme Court has been spotty. ${ }^{135}$ In the privacy context the Court has ruled that privacy-invading speech that deals with "matters of public interest" 136 or "events of legitimate concern to the public"137 cannot constitutionally serve as the predicate for public disclosure liability, but without firmly tying the legitimate interest test to the governing responsibilities of the people.

The Court's only effort to state the standard by which the public interest in private facts is to be assessed was in Time, Inc. $v$. $H i l l,{ }^{138}$ where, quoting from Thornhill $v$. Alabama, ${ }^{139}$ it stated: "Freedom of discussion, if it would fulfill its historic function in this nation, must embrace all issues about which information is needed or appropriate to enable the members of society to cope with the exigencies of their period." 140

The obvious difficulty with the Thornhill formula, as with other

13 See A. Meiklejohn, Free Speech and its Relation to Self-Government 94 (1948). Speech which is not relevant to self-government is, in Meiklejohn's view, protected only by due process guarantees. Id. at 39 .

${ }^{13}$ Meiklejohn, The First Amendment is an Absolute, 1961 Sup. CT. Rev. 245, 262.

${ }^{135}$ See generally Bloustein, supra note 8; Brennan, The Supreme Court and the Meiklejohn Interpretation of the First Amendment, 79 HARv. L. REv. 1 (1965).

136 Time, Inc. v. Hill, 385 U.S. 374, 388 (1967).

${ }_{137}$ Cox Broadcasting Corp. v. Cohn, 420 U.S. 469, 492 (1975).

138385 U.S. 374 (1967).

139310 U.S. 88,102 (1940).

140385 U.S. at 388. 
attempts to draw a line between public and private speech, ${ }^{141}$ is its vagueness. ${ }^{142}$ Supreme Court decisions inform us that a rape victim's name ${ }^{143}$ and the travail of a family once held kidnapped in their own home $\mathrm{e}^{14}$ are newsworthy. But the Court has not explained how knowledge of such facts prepares any member of society for the exigencies of our day. A plausible explanation of the determinations of newsworthiness made in Hill and Cohn, strongly supported by the language of the opinions, is that the Court, convinced that discussion of crime is important speech deserving constitutional protection, did not bother with evaluating the public importance of the particular private facts disclosed. Yet it should be recognized that there are public aspects to every subject. ${ }^{145}$ If a single public aspect renders an entire subject newsworthy, then the public disclosure tort is unconstitutional.

However, a reasonable alternative to this conclusion exists. By focusing on the potential area of conflict between the public disclosure tort and freedom of press and speech, first amendment interests can be preserved without completely sacrificing privacy inter-

Is A number of proposals for distinguishing public speech from private speech surfaced in the wake of New York Times Co. v. Sullivan, 376 U.S. 254 (1964). See, e.g., Note, Free Speech and Defamation of Public Persons: The Expanding Doctrine of New York Times Co. v. Sullivan, 52 CoRnel L.Q. 419, 425 (1967) ("public decisionability"); Comment, The Limits of Political Speech: New York Times v. Sullivan Revisited, 14 U.C.L.A. L. REv. 631, 648 (1967) (matter of legitimate public concern); Note, The Scope of First Amendment Protection for Good-Faith Defamatory Error, 75 Yale L.J. 642, 652 (1966) (issue of legitimate public concern).

Judge Skelly Wright has suggested that the category of matters of public interest encompasses "those subjects in which the community as a whole has an interest." Wright, Defamation, Privacy, and the Public's Right to Know: A National Problem and a New Approach, 46 TEx. L. REv. 630, 636 (1968).

142 The Supreme Court has stated in a number of criminal cases that a rule of law "which either forbids or requires the doing of an act in terms so vague that men of common intelligence must necessarily guess as to its meaning and differ as to its application, violates the first essential of due process." Connally v. General Constr. Co., 269 U.S. 385, 391 (1926), quoted in Zwickler v. Koota, 389 U.S. 241, 249 (1968) (dictum). Moreover, the Court has indicated that stricter standards of permissible vagueness may be applied if erratic application of the particular rule of law would inhibit exercise of first amendment freedoms: "a man may the less be required to act at his peril here, because the free dissemination of ideas may be the loser." Smith v. California, 361 U.S. 507, 517-18 (1959) (dictum); Winters v. New York, 333 U.S. 507, 515-18 (1948). See generally Note, The Void-for-Vagueness Doctrine in the Supreme Court, 109 U. PA. L. REv. 67 (1960).

143 Cox Broadcasting Corp. v. Cohn, 420 U.S. 469 (1975).

is Time, Inc. v. Hill, 385 U.S. 374 (1967).

is But cf. T. Emerson, The System of Freedom of Expression 557 (1970). Professor Emerson, thinking attempts to draw "fine distinctions as to whether the communication has great or small social value" futile, $i d$. at 556, and at odds with "the whole idea of the First Amendment," $i d$. at 554, proposes that all privacy-invading communications which invade the "inner core of intimacy" be actionable while all other disclosures be protected, $i d$. at 557 . 
ests. A right of action for invasion of privacy does not arise because "events" or "matters" have been disclosed. Rather, the privacy tort is concerned solely with private facts whose disclosure harms a reasonable sense of individual dignity. Indeed, inquiring whether the private facts disclosed are of first amendment importance is also unnecessarily wide-ranging. Association of private facts with particular individuals will often neither increase public sensitivity nor in any way prepare people for dealing with their own responsibilities and problems. Moreover, individual privacy is not seriously harmed by stories which disclose private facts but do not associate those facts with particular people. ${ }^{146}$ Accordingly, if the legitimate public interest in an event or fact is as well served by a story that does not identify individuals as one that does, both first amendment and privacy interests may be preserved by publication of the former, and not the latter, story.

Furthermore, determining if there exists a legitimate public interest in knowing that certain private facts pertain to a given individual is a less unwieldy task than deciding what private facts are newsworthy. For example, the horror of rape may be pointedly conveyed by a detailed account of a rape omitting the name of the victim. The simplification consists in circumventing the determination of whether the public has a legitimate interest in knowing the details of a particular rape. Only the public interest in the fact which directly conflicts with privacy interests, individual identity, need be assessed. Of course, identifying individuals in privacyinvading stories may serve legitimate public interests. A clear case is a report revealing that a political candidate has a drinking problem, because personal identification is directly pertinent to informed exercise of the vote. ${ }^{147}$

is Identification of individuals is not confined to printing names or publishing photographs. Identification may also occur when information in any way links the private facts disclosed with a particular individual so as to inform an appreciable number of people (who may or may not know the individual in question) that the private facts refer to the particular individual.

Bloustein has recognized the crucial role of personal identification in applying the newsworthiness defense, although in his view newsworthiness, defined narrowly in terms of relevance to self-government, should be the only constitutional defense to privacy actions. See Bloustein, supra note 8, at 65-69; cf. Meeropol v. Nizer, 560 F.2d 1061 (2d Cir. 1977), cert. denied, 46 U.S.L.W. 3427 (Jan. 9, 1978) (court holds identification of plaintiff to be indispensable to maintenance of defamation and false light identification).

${ }^{317}$ Whether identification of the plaintiff is newsworthy under the test outlined in this comment will not depend on the plaintiff's status as a public figure vel non. Reporting that the relatively unknown local church leader was arrested for drunken driving should be protected as an illustration of human hypocrisy. Publishing a photograph of Mrs. Onassis sunbathing without benefit of a bathing suit should not be protected because the public has no legitimate concern with the private facts disclosed. 
It might be urged that the proposed method of assessing newsworthiness would in practice unjustifiably inhibit press freedom-that stories will seldom identify individuals because publishers and writers will wish to avoid constantly having to ascertain what information is of legitimate public concern. This objection is unpersuasive. Most stories do not reveal private facts. Most stories revealing private facts and associating them with individuals do not occasion the serious injury to individual dignity which the offensive disclosure standard requires. Instances in which the press must make newsworthiness judgments would be rare and, due to the actual knowledge/standard of care requirement, apparent. ${ }^{148}$

It might be thought desirable for the courts to adopt an actual knowledge/standard of care requirement under which a publisher making a reasonable but mistaken judgment that a privacyinvading story is newsworthy would be protected from liability. Moreover, consistency with the treatment of the offensive disclosure requirement proposed above might appear to argue for an actual knowledge/standard of care requirement with respect to newsworthiness. ${ }^{149}$

However, the analogy to the actual knowledge/standard of care requirement advocated with respect to the offensive disclosure requirement is not convincing. The function of the actual knowledge/standard of care requirement with respect to offensiveness is to ensure that the defendant is immune from liability when his mistake in judgment is due to a lack of knowledge of the plaintiff's situation. The actual knowledge/standard of care requirement with respect to offensiveness also ensures that the defendant is cognizant of the facts whose newsworthiness must be determined. If the defendant reasonably but erroneously believes that the publication does not identify individuals, he would not be charged with knowledge of the facts that render the disclosure offensive and thus would not be required to determine whether the identification is newsworthy. Therefore, newsworthiness need not be supplemented by an actual knowledge/standard of care requirement. Nor should the defendant's claim that he reasonably but erroneously believed his disclosure was newsworthy be credited. Newsworthiness is a purely legal concept based on assessment of the first amendment value of the speech involved. If a publisher schooled in privacy law can make a

14 Moreover, establishment of specific precedents determining when particular private facts are newsworthy will further alleviate the potential vagueness problems caused by the lack of precision in the definition of newsworthiness.

iv See text and notes at notes 130-132 supra. 
reasonable but mistaken judgment as to the newsworthiness of an item, then the doctrine fails to afford adequate notice, and the public disclosure tort is unconstitutionally vague. ${ }^{150}$ If the publisher's mistaken judgment is due to a lack of legal erudition, then his reasonableness ought to be no defense. As the Supreme Court stated in Hamling $v$. United States, ${ }^{151}$ an obscenity case:

It is constitutionally sufficient that the prosecution show that a defendant [charged with knowingly using the mails to carry obscene brochures] had knowledge of the contents of the material distributed, and that he knew the character and nature of the materials. To require proof of a defendant's knowledge of the legal status of the materials would permit the defendant to avoid prosecution by simply claiming that he had not brushed up on the law.

C. The Allocation of Judgmental Responsibility between Judge and Jury

The constitutional standards articulated above for accommodating the public disclosure tort with the first amendment are not self-executing guardians of first amendment freedoms. However, the offensive disclosure requirement, the actual knowledge/ standard of care requirement and the newsworthiness privilege are sufficiently certain and definite to apprise publishers of when publication of privacy-invading stories can constitutionally give rise to tort liability, provided that trial judges and reviewing courts are entrusted with certain important functions in administering these constitutional standards.

The Supreme Court has not discussed the appropriate division of judgmental responsibility between trial judge, jury, and appellate court in adjudicating first amendment defenses to public disclosure suits. There is considerable disagreement among the lower courts on whether the question of newsworthiness, the only constitutional privilege presently accepted, is for the judge or jury to resolve. ${ }^{152}$ However, a number of Supreme Court opinions, ${ }^{153}$ primarily in the

iso See Smith v. California, 361 U.S. 147, 151-55 (1959).

131418 U.S. 87, 123 (1974).

132 See, e.g., Virgil v. Time, Inc., 527 F.2d 1122, 1130 \& n.13 (9th Cir. 1975), cert. denied, 425 U.S. 998 (1976) (newsworthiness a jury issue); Neff v. Time, Inc., 406 F. Supp. 858 (W.D. $\mathrm{Pa}$. 1976) (newsworthiness to be resolved by the judge); Taylor v. K.T.V.B., Inc., 96 Idaho 202, 206, 525 P.2d 984, 988 (1974) (malice a jury question); McNutt v. New Mexico State Tribune Co., 88 N.M. 162, 169, 538 P.2d 804, 811 (1975) (newsworthiness a question for the court).

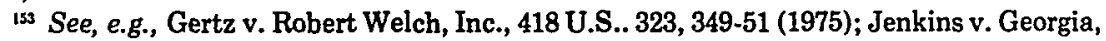


libel and obscenity areas, indicate that procedural safeguards play an indispensable role in protecting first amendment freedoms, and consistency argues that the principles of "first amendment due process"154 established by the Court should be applied in the privacy area.

One principle of importance to constitutional administration of privacy suits has emerged from the Court's quest for "sensitive tools"155 for appraising first amendment claims: trial judges ${ }^{156}$ and reviewing courts ${ }^{157}$ must independently ${ }^{158}$ evaluate the character of speech to determine what, if any, measure of constitutional protection its enjoys. ${ }^{159}$ The rationales proffered for this rule include the plausible though unproven assertions that juries are more apt to use their discretion selectively to punish unpopular views or speakers, ${ }^{160}$ that under a system of general verdicts juries are unlikely to carefully consider each discrete first amendment issue, ${ }^{161}$ that judges are

418 U.S. 153, 160-61 (1974); Time, Inc. v. Pape, 401 U.S. 279, 291 (1971); Monitor Patriot Co. v. Roy, 401 U.S. 265, 277 (1971); Curtis Publishing Co. v. Butts, 388 U.S. 130, 152 (1967); Rosenblatt v. Baer, 383 U.S. 75, 88 n.15 (1966); Freedman v. Maryland, 380 U.S. 51,58 (1965); Jacobellis v. Ohio, 378 U.S. 184, $187-88$ (1964); Speiser v. Randall, 357 U.S. 513, 52021 (1958).

15t This phrase served as the title of an interesting law review article, Monaghan, First Amendment "Due Process," 83 HaRv. L. Rev. 518 (1970).

iss Speiser v. Randall, 357 U.S. 513, 525 (1958).

ist In the defamation area, the Supreme Court has ruled that "as is the case with questions of privilege generally, it is for the trial judge in the first instance to determine whether the proofs show [the plaintiff] to be a 'public official'". Rosenblatt v. Baer, 383 U.S. 75, 88 (1966). Similarly, the trial judge is to make an independent assessment of the facts in an obscenity case to determine whether the material is obscene or constitutionally protected. Clicque v. United States, 514 F.2d 923, 925-26 (5th Cir. 1975).

${ }_{157}$ See, e.g., Jenkins v. Georgia, 418 U.S. 153, 161 (1974) (obscenity vel non resolved de novo); Curtis Publishing Co. v. Butts, 388 U.S. 130, 154-55 (1967) (opinion of Harlan, J.) (plaintiff's status as a public figure determined); Jacobellis v. Ohio, 378 U.S. 184, 187-90 (1964) (opinion of Brennan, J.) (obscenity vel non resolved de novo); Pennekamp v. Florida, 328 U.S. 331,335 (1946) (whether speech presented a clear and present danger determined independently of state court's finding).

${ }_{13 s}$ The trial judge should resolve the question of the extent of constitutional protection afforded the speech before submitting the case to the jury and if the speech is found absolutely protected, the jury is precluded from acting. See cases cited in note 156 supra; Monaghan, supra note 154, at 531. Similarly, the appellate court need accord no deference to the determinations of the trial judge or jury regarding the attributes of the speech itself. See cases cited note 157 supra.

159 Compare the Supreme Court's established power to make an independent judgment on questions of law application on appeals from state courts where the basic facts are undisputed and a federal right is at stake. See, e.g., Drope v. Missouri, 420 U.S. 162, 174-75 (1975); Watts v. Indiana, 338 U.S. 49, 51 (1949). See generally Hill, The Inadequate State Ground, 65 Colum. L. REv. 943, 946-48 (1965); Note, Supreme Court Review of State Findings of Fact in Fourteenth Amendment Cases, 14 Stan. L. REv. 328 (1962).

${ }^{160}$ Rosenblatt v. Baer, 383 U.S. 75, 88 n.15 (1966).

11' Monaghan, supra note 154, at 530. 
more experienced in making the sort of value judgments required, ${ }^{162}$ and that judges are more inclined to realize the importance of first amendment values. ${ }^{163}$ To this list may be added the desirability of establishing and following precedents delineating the categories of protected speech so as to provide a surer guide to publishers and speakers.

In contrast, juries are authorized to resolve questions of fault, ${ }^{164}$ thereby potentially defeating the protection accorded speech, ${ }^{165}$ and the inquiry undertaken by appellate courts is confined to determining whether the evidence is sufficient to sustain the jury's finding. In the defamation area the Court has justified this allocation by explaining that, because a state of mind element is neutral with respect to the content of speech, it does not present "a real danger of becoming an instrument for the suppression of those 'vehement, caustic and unpleasantly sharp attacks' . . . which must be protected if the guarantees of the First and Fourteenth Amendment are to prevail." 166

The distinction drawn by the Court between determinations which depend upon content and those which turn upon the speaker's state of mind, allocating only the latter to the jury, compels a particular allocation of judgmental authority with respect to most of the elements of the proposed model. It clearly requires that the initial determination of newsworthiness, be made by the trial

${ }_{162}$ Lockhart \& McClure, Censorship of Obscenity: The Developing Constitutional Standards, 45 MiNN. L. REv. 5, 119 (1960), cited with approval in Jacobellis v, Ohio, 378 U.S. 184, 188 n.3 (1964) (opinion of Brennan, J.).

163 Monaghan, supra note 154, at 529.

${ }^{164}$ See, e.g., Time, Inc. v. Firestone, 424 U.S. 448, 461, 463-64 (1976) (defamation suit by private figure remanded to the state court to determine negligence vel non of defendant publisher); Hamling v. United States, 418 U.S. 87, 124 (1974) (jury's finding of scienter required for conviction under 18 U.S.C. $\& 1461$ (1970) for mailing and conspiring to mail obscene brochures upheld because there was substantial evidence, taking the view most favorable to the government, to support it); St. Amant v. Thompson, 390 U.S. 727, 731 (1968) (to sustain a jury's finding of "actual malice" in a defamation suit there must be sufficient evidence showing "that the defendant in fact entertained serious doubts as to the truth of his publication"). But see Time, Inc. v. Pape, 401 U.S. 279, 292 (1971) (a rational interpretation of an ambiguous document held as a matter of law not to constitute actual malice).

185 Proof of actual malice defeats the constitutional protection afforded defamatory speech about public figures. Time, Inc. v. Hill, 385 U.S. 374 (1967). Similarly, proof of negligence is sufficient to overcome the constitutional protection afforded defamatory speech about private individuals. See generally Gertz v. Robert Welch, Inc., 418 U.S. 323 (1974). Scienter is at issue in an obscenity case only if the material is unprotected. See Hamling v. United States, 418 U.S. 87, 119-24 (1974).

${ }^{186}$ Monitor Patriot Co. v. Roy, 401 U.S. 265, 277 (1971) (quoting New York Times Co. v. Sullivan, 376 U.S. 254, 270 (1964)); see Curtis Publishing Co. v. Butts, 388 U.S. 130, 153 (1967) (opinion of Harlan, J.). 
judge subject to unfettered appellate review. ${ }^{187}$ Newsworthiness involves assessing the content of speech to determine if it is a permissible predicate for tort liability. Accordingly, the need for the dispassionate, experienced judgment and the perceived sensitivity to first amendment values of the bench is very great. Moreover, precedents concerning newsworthiness will provide the press with needed guidance.

Similar reasoning and assumptions support entrusting trial and appellate judges with responsibility for administering the standard of care defense-that is, deciding whether privacy-invading speech is, on its face, injurious to a reasonable sense of individual dignity. This allocation of responsibility is also mandated by the purpose of the standard of care defense, ensuring that publishers may be fairly chargeable with knowledge that they are harming legitimate privacy interests. Of course, insisting that the judge independently determine this, or any other, question need not preclude a jury from also passing on the issue; ${ }^{168}$ for example, if the judge determines that a disclosure is unnewsworthy, he could still permit the jury to find for the defendants on the ground that the disclosure was newsworthy.

On the other hand, the jury should be charged with primary responsibility for ascertaining whether the defendant in fact knew that the disclosure complained of would injure legitimate privacy interests. The slim role of this element of the proposed model is to determine if by virtue of special knowledge the defendant in fact knew that a story superficially innocuous was destructive of a reasonable sense of individual dignity. This element is unrelated to the content of the disclosure, and consistency with administration of the fault requirements in obscenity and defamation cases demands that the jury resolve this question of scienter.

The requirement that the disclosure offend a reasonable sense of individual dignity is not captured by the dichotomous çlassification of determinations that turn on the content of speech and determinations that relate to the defendant's state of mind. Unconnected to evaluation of the content of speech or the defendant's state of mind, the offensive disclosure inquiry asks whether the facts disclosed are private facts an individual in the plaintiff's position could reasonably want to keep private.

Exacerbating the uncertainty caused by the absence of control-

107 The Court has twice independently determined the newsworthiness of private facts. Cox Broadcasting Corp. v. Cohn, 420 U.S. 469, 495 (1975); Time, Inc. v. Hill, 385 U.S. 374 (1967).

is See Monaghan, supra note 154, at 531-32. 
ling authority, the principles governing the division of judgmental authority between.judge and jury provide conflicting instruction with respect to the offensive disclosure requirement. Phrased in terms of reasonableness, the requirement incorporates community standards to define the range of facts whose disclosure is proscribed by the public disclosure tort. On this score, the jury, as the embodiment of community standards, is the preferred arbiter of the offensive disclosure requirement. However, the premises of jury prejudice and contumacy that undergird the Court's confinement of the jury's role in cases involving sensitive first amendment interests appear to mandate committing the task of applying the offensive disclosure requirement to the trial judge, subject to de novo appellate review. Granting a jury authority to determine what private facts may be protected through operation of law as well as responsibility for resolving the state of mind question would remit publishers and speakers to sole reliance on the newsworthiness defense for vindication of their first amendment rights. Moreover, in passing on the standard of care question, judges necessarily determine what disclosures of private facts are offensive. The formal point that the standard of care defense as outlined in this comment involves assessing. the content of speech while the offensive disclosure inquiry technically does not is an insufficient ground for distinguishing between closely related judgments, both of which determine the measure of constitutional protection afforded true speech.

\section{Conclusion}

In a public disclosure action the plaintiff seeks to have the defendant adjudged liable in tort for truthfully disclosing private facts. Recognizing the ineluctable conflict between unrestricted operation of the public disclosure tort and freedom of speech and press, courts have ruled that a privacy action may constitutionally be maintained only if the facts disclosed are not of legitimate public interest. This comment has attempted to show that the several discernible points of conflict between the public disclosure tort and first amendment freedoms are not resolved by invocation of the newsworthiness defense, in any of its variant formulations. Undertaking to reach a principled and administrable accommodation between the privacy tort and the first amendment, the comment has argued that a public disclosure action is constitutionally maintainable only when the disclosure of unnewsworthy private facts seriously harms the plaintiff's reasonable sense of individual dignity and the defendant is fairly chargeable with cognizance of the dignitary harm caused by his disclosure. The proposed model illustrates the concep- 
tually rich and thorough-going tension between contemporary first amendment principles and the tort inspired by a distinguished law review article written some eighty-seven years ago.

Jeffrey C. Martin 